\title{
PENGEMBANGAN LEMBAR KERJA SISWA (LKS) BERMUATAN KARAKTER UNTUK MENINGKATKAN HASIL BELAJAR IPA
}

\author{
Berwina Ngalemisa Br Tarigan \\ Program Studii Teknologi Pendidikan, Universitas Pendidikan Ganesha \\ wienatarigan@yahoo.co.id \\ Anak Agung Gede Agung \\ Program Studii Teknologi Pendidikan, Universitas Pendidikan Ganesha \\ agung2056@undiksha.ac.id \\ Desak Putu Parmiti \\ Program Studii Teknologi Pendidikan, Universitas Pendidikan Ganesha \\ db-parmiti@undiksha.acv.id
}

\begin{abstract}
Abstrak
Permasalahan yang terjadi di kelas V SD Negeri 1 Banjar Bali adalah kurangnya bahan ajar yang dapat menunjang pembelajaran siswa secara mandiri. Bahan ajar yang digunakan hanyalah buku cetak yang secara keseluruhan di dominasi oleh sajian teks saja. Penelitian ini bertujuan untuk (1) untuk menggambarkan rancang bangun pengembangan Lembar Kerja Siswa Bermuatan Karakter yang dikembangkan, (2) untuk mengetahui validitas pengembangan Lembar Kerja Siswa Bermuatan Karakter, (3) untuk mengetahui efektivitas pengembangan Lembar Kerja Siswa Bermuatan Karakter. Metode pengumpulan data yang digunakan, yaitu: (1) metode kuisioner, dan (2) tes obyektif tipe pilihan ganda. Analisis data menggunakan analisis deskripstif kualitatif, kuantitatif dan statistik inferensial/induktif uji-t.(1) Rancang Bangun Lembar Kerja Siswa Bermuatan Karakter meliputi 5 tahapan: tahap Analisis (Analysis), Tahap perancangan (Design), Tahap pengembangan (Development), Tahap Implementasi (Implementation), Tahap evaluasi (evaluation). (2) Lembar Kerja Siswa bermuatan karakter valid dengan: (a) hasil review ahli isi mata pelajaran menunjukkan Lembar Kerja Siswa bermuatan karakter berpredikat sangat baik (100\%), (b) hasil review ahli desain pembelajaran menunjukkan Lembar Kerja Siswa Bermuatan Karakter berpredikat sangat baik $(92,63 \%)$, (c) hasil review ahli media pembelajaran menunjukkan Lembar Kerja Siswa Bermuatan Karakter berpredikat baik (77,93\%), (d) hasil review uji coba perorangan menunjukkan Lembar Kerja Siswa Bermuatan Karakter berpredikat sangat baik (91,20\%), (e) hasil review uji coba kelompok kecil menunjukkan Lembar Kerja Siswa Bermuatan Karakter berpredikat sangat baik $(95,11 \%$ ), (f) hasil review uji coba lapangan menunjukkan Lembar Kerja Siswa Bermuatan Karakter berpredikat sangat baik (93,76\%). (3) LKS IPA bermuatan karakter yang dikembangkan efektif meningkatkan hasil belajar IPA (thitung $=4.077>$ ttabel $=1,67155$ pada taraf signifikansi 5\%).
\end{abstract}

Kata Kunci: aktivitas higher order thinking, inkuiri terbimbing, perangkat pembelajaran

\begin{abstract}
The problem that occurs in the fifth grade of SD Negeri 1 Banjar Bali is the lack of teaching materials that can support student learning independently. The teaching materials used are only printed books which are entirely dominated by textual content.This study aims to (1) describe the design of the development of Character-included Student Worksheets developed, (2) to determine the validity of the development of Character-included Student Worksheets, (3) to determine the effectiveness of developing Character-included Student Worksheets. Data collection methods used, namely: (1) questionnaire method, and (2) multiple choice type objective tests. Data analysis uses descriptive qualitative, quantitative and inferential / inductive statistical t-test analysis (1) Character Building Worksheets with Character Contents include 5 stages: Analysis stage, Design stage, Development stage, Implementation stage, evaluation stage. (2) Character-included Student Worksheets are valid with: (a) the results of the review from experts in subjects' contents show that Characterincluded Student Worksheets are very good $(100 \%)$, (b) the results of review from experts in learning design show a Character-included Student Worksheets are very good (92.63\%), (c) the results of the review from experts in instructional media show Character-included Student Worksheets have good credentials (77,93\%), (d) the results of individual trial reviews show Character-included Student Worksheets have very good predicate $(91.20 \%)$, (e) the results of a small group trial review show Character-included Student Worksheets have very good predicate $(95.11 \%$ ), (f) the results of the field trial review show Character-included Student Worksheets have very good predicate $(93.76 \%$ ) (3) Character-included Student Worksheets developed effectively improve science learning outcomes ( $\mathrm{t}$ count $=4,077$ for $\mathrm{db}=58$ and significant level $5 \%$ t table $=1.67155$ ). This means that Student Character-included Worksheets are proven to be significantly effective in improving science learning outcomes.
\end{abstract}

Keywords: LKS, character oriented, ADDIE, development 


\section{Pendahuluan}

Pendidikan adalah usaha sadar dan terencana untuk mewujudkan suasana belajar dan proses pembelajaran agar peserta didik secara aktif mengembangkan potensi dirinya untuk memiliki kekuatan spiritual keagamaaan, pengendalian diri, kepribadian, kecerdasan, akhlak mulia, serta ketrampilan yang diperlukan dirinya, masyarakat, bangsa, dan Negara. Pendidikan mempunyai arti penting dalam kehidupan, karena melalui pendidikan akan tercipta sumber daya manusia yang cerdas dan berkualitas. pendidikan secara sederhana dapat diartikan sebagai usaha manusia untuk membina kepribadiannya sesuai dengan nilai-nilai di dalam masyarakat dan kebudayaannya. Dengan demikian, bagaimanapun sederhananya peradaban suatu masyarakat, didalamnya terjadi atau berlangsung suatu proses pendidikan. Karena itulah sering dinyatakan pendidikan telah ada sepanjang peradaban umat manusia (UU No. 20 Tahun 2003). Berbicara tentang pendidikan tentunya tidak jauh dari kata proses pembelajaran, media pembelajaran, dan belajar.

Nichol (dalam Aunurrahman, 2012:33) mengatakan belajar merupakan kegiatan penting setiap orang, termasuk di dalamnya belajar bagaimana seharusnya belajar. Sebuah survey memperlihatkan bahwa $82 \%$ anakanak yang masuk sekolah pada usia 5 atau 6 tahun memiliki citra diri yang positif tentang kemampuan belajar mereka sendiri. Tetapi angka tinggi tersebut menurun drastis menjadi hanya $18 \%$ waktu mereka berusia 16 tahun. Konsekuensinya, 4 dari 5 remaja dan orang dewasa memulai pengalaman belajarnya yang baru dengan perasaan ketidaknyamanan. Belajar merupakan aktivitas mental atau psikis yang dilakukan oleh seseorang sehingga menimbulkan perubahan tingkah laku yang berbeda antara sesudah belajar dan belum belajar. Tentunya dalam belajar pasti akan mengalami proses pembelajaran yang dimana dalam prosesitu terdapat seorang siswa atau peserta didik dan seorang pengajar atau guru.

Pembelajaran merupakan suatu sistem yan memiliki komponen-komponen pembelajaran, (1) peserta didik, (2) proses pembelajaran, (3) lulusan dengan kompetensi yang diharapkan, (4) pendidik, (5) kurikulum dan (6) bahan pembelajaran,komponen tersebut saling berkaitan dan terintegrasi menjadi satu fungsi dalam mencapai tujuan, sehingga seluruh komponen haruslah diperhatikan jika ada salah satu komponen tidak terintegrasi dengan tepat maka tujuan pembelajaran tidak tercapai secara optimal (parmiti 2014).

Proses pembelajaran dibangun berdasarkan strategi pembelajaran tertentu. Strategi pembelajaran yang efektif adalah pembelajaran yang mampu membawa peserta didik mencapai tujuan/kompetensi yang diharapkan. Untuk menciptakan proses pembelajaran yang efektif Smaldino et al (dalam parmiti, 2014) menyatakan ada beberapa hal yang perlu di perhatikan yaitu, (1) peran aktif siswa, (2) pemberian latihan, (3) perhatian terhadap adanya perbedaan individual, (4) pemberian umpan balik, dan (5) penerapan pengetahuan dan keterampilan dalam situasi nyata.

Pengembangan bahan ajar penting dilakukan oleh pendidik agar pembelajaran lebih efektif, efisien, dan tidak keluar dari kompetensi yang ditetapkan pada kurikulum 2013. Bahan ajar merupakan segala bentuk bahan yang dapat digunakan oleh pendidik untuk membantu dalam melaksanakan kegiatan belajar mengajar dikelas. Bahan ajar sangat penting untuk dikembangkan sebagai upaya untuk meningkatkan kualitas pembelajaran. Maksud dari tuntutan kurikulum 2013 adalah standar kompetensi lulusan ditetapkan oleh pemerintah, namun bagaimana untuk mencapai tujuan pembelajaran dan bahan ajar apa yang akan digunakan sepenuhnya diserahkan kepada pendidikan sebagai tenaga profesional. Kurikulum 2013 adalah standar kompetensi lulusan ditetapkan oleh pemerintah, namun bagaimana untuk mencapai tujuan pembelajaran dan bahan ajar apa yang akan digunakan sepenuhnya diserahkan kepada pendidik sebagai tenaga profesional. Kurikulum 2013 menekankan bahwa sumber belajar dan bahan ajar sangat erat hubungannya erat dengan proses belajar siswa. Terdapat bahan ajar yang dikemas dalam bentuk cetak (printed), bahan ajar dengar (audio), bahan ajar pandang dengar (audio visual), dan bahan ajar interaktif (interactive teaching material). Salah satu bahan ajar cetak yang dapat digunakan untuk membantu proses pembelajaran adalah LKS.

Lembar Kerja Siswa (LKS) pada umumnya dibeli dan bukan dibuat sendiri oleh guru. Padahal, LKS bisa dibuat sendiri dan bisa jauh lebih menarikserta kontekstual sesuai situasi dan kondisi sekolah ataupun lingkungan sosial budaya siswa. Untuk itu, kita hanya perlu memahami lima point penting berikut ini, yaitu: pengertian Lembar Kegiatan Siswa (LKS), fungsi, tujuan, dan kegunaan LKS dalam pembelajaran tematik, jenis-jenis LKS, unsur-unsur LKS sebagai bahan ajar, langkah-langkah aplikatif membuat LKS, dan mengembangkan LKS menjadi "kaya manfaat" (dalam prastowo 2014: 268). Lembar kerja siswa adalah lembaran-lembaran berisi tugas yang harus dikerjakan oleh siswa. LKS biasanya berupa petunjuk dan langkahlangkah untuk menyelesaikan suatu tugas. Bentuk-bentuk LKS terdiri dari LKS eksperimen berupa lembar kerja yang memuat petunjuk praktikum yang menggunakan alat-alat dan bahan-bahan. LKS non eksperimen berupa lembar kegiatan yang memuat teks yang menuntut siswa melakukan kegiatan diskusi suatu materi pelajaran. Lembar Kegiatan Siswa adalah panduan siswa yang digunakan untuk melakukan kegiatan penyelidikan atau pemecahan masalah. Lembar Kegiatan Siswa dapat berupa panduan untuk latihan pengembangan aspek kognitif maupun panduan untuk pengembangan semua aspek pembelajaran dalam bentuk panduan eksperimen atau demonstrasi. Penggunaan media memberikan manfaat dalam proses pembelajaran, hal ini dikemukakan oleh Arsyad 2011 antara lain yaitu, (1) Media pembelajaran dapat memperjelas penyajian pesan dan informasi sehingga proses belajar semakin lancar dan meningkatkan hasil belajar, (2) Media pembelajaran dapat 
meningkatkan motivasi siswa, dengan mengarahkan perhatian siswa sehingga memungkinkan siswa belajar sendiri-sendiri sesuai kemampuan dan minatnya, (3) Media pembelajaran dapat mengatasi keterbatasan indera, ruang, dan waktu, (4) Media pembelajaran dapat memberikan kesamaan pengalaman kepada siswa tentang peristiwa-peristiwa di lingkungan mereka, serta memungkinkan terjadinya interaksi langsung dengan guru, masyarakat, dan lingkungannya.

Melihat pengertian tentang LKS secara garis besarnya yaitu bahan ajar yang memiliki peran sebagai berikut. (1) LKS sebagai bahan ajar yang dapat minimalkan peran pendidik dan lebih mengoptimalkan peran peserta didik. (2) sebagai bahan ajar yang mempermudah peserta didik untuk memahami materi yang diberikan. (3) sebagai bahan ajar yang ringkas dan kaya tugas untuk berlatih. Dan yang terakhir (4) memudahkan pelaksanaan pembelajaran kepada peserta didik (Parmiti, 2014). Dari peran tersebut maka pengembangan LKS sangatlah tepat guna memfasilitasi proses pembelajaran untuk meningkatkan hasil belajar siswa. Penggunaan media yang masih sangat konvensional seperti papan tulis dan, dirasakan kurang efisien, baik efisien waktu saat penggunaan, efisien dalam pembelajaran, dan efisien dana. Hal ini sangat berpengaruh terhadap minat dan motivasi siswa untuk belajar. Rencana pengembangan Lembar Kerja Siswa (LKS) ini akan disajikan dalam bentuk bermuatan karakter, karena melalui bermuatan karakter siswa akan berperan aktif serta mandiri dan bertanggung jawab mengenali dan menemukan informasi, mengolah, dan mengambil keputusan, serta memecahkan masalah secara kreatif dengan melakukan percobaan eksperimen untuk memperkuat pengetahuan siswa terhadap materi pembelajaran. Dalam pembelajaran, Pendidikan karakter sangat diperlukan. Setiawati (2017:348) berpendapat bahwa "Pendidikan karakter merupakan suatu hal yang sangat penting dalam membangun bangsa yang beradab dan bermartabat, baik di mata Tuhan, dunia internasional, dan manusia". Membuat peserta didik berkarater adalah tugas pendidikan, yang esensinya adalah membangun manusia seutuhnya, yaitu manusia yang baik dan berkarakter. Pengertian baik dan berkarakter mengacu pada norma yang dianut, yaitu nilai-nilai luhur pancasila. Seluruh butir-butir pancasila sepenuhnya terintegrasi ke dalam harkat dan martabat manusia (HMM). HMM terdiri atas tiga komponen, yaitu hakikat manusia, pancadaya kemanusiaan, dan dimensi kemanusiaaan Alwis (dalam Setiawati 2017:349).

Adapun tujuan pendidikan karakter yang sesungguhnya jika dihubungkan dengan falsafah Negara Republik Indonesia adalah mengembangkan karakter peserta didik agar mampu mewujudkan nilai-nilai luhur pancasila. Menurut Alwis (dalam Setiawati 2017:349 ) fungsi Pendidikan karakter sebagai berikut.

Fungsi pendidikan karakter adalah sebagai berikut. 1. Pengembangan potensi dasar, agar berhati baik, berpikiran baik, dan berperilaku baik". 2. Perbaikan perilaku yang kurang baik dan penguatan perilaku yang sudah baik. 3. Penyaringan budaya yang kurang sesuai dengan nilai-nilai luhur pancasila. Kemudian, ruang lingkup atau sasaran dari pendidikan karakter adalah: 1. Satuan pendidikan 2. Keluarga 3. Masyarakat

Kenyataan tentang merosotnya moral inilah yang kemudian menempatkan pentingnya penyelengaraan pendidikan karakter. Rujukan kita sebagai orang yang beragama terkait dengan problem moral dan pentingnya pendidikan karakter. Menurunnya kualitas moral dalam kehidupan manusia dewasa ini, terutama di kalangan siswa, dituntut diselenggarakannya pendidikan karakter. Sekolah dituntut untuk memainkan peran dan bertanggung jawab untuk menanamkan dan mengembangkan nilai-nilai yang baik dan membantu para siswa membentuk serta membangun karakter

Ketika melaksanakan observasi dan wawancara dengan salah satu guru wali kelas V SD Negeri 1 Banjar Bali yaitu ibu Ni Luh Raka Tirtawati, S.Pd.SD pada tanggal 19 desember 2018, beliau mengatakan bahwa saat proses pembelajaran guru terkadang menggunakan media dalam mata pelajaran lain, itupun jika ada media yang sesuai dengan materi saat itu. Selain itu beliau juga mengatakan terkadang kesulitan menyampaikan materi kepada siswa karena sangat dibutuhkan materi untuk siswa pelajari pada saat sedang di rumah agar menambah wawasan serta pengetahuan lebih kepada siswa, agar media tersebut berguna untuk menambah wawasan mereka serta melatih daya ingat dan tidak hanya digunakan di sekolah saja melainkan bisa dibawa kerumah.

Berdasarkan hasil wawancara dengan Ibu Raka, mengatakan bahwa pengembangan bahan ajar cetak seperti Lembar Kerja Siswa (LKS), dirasa para siswa dan guru sangat membutuhkan media pembelajaran cetak dan bahan pembelajaran yang relevan. Penggunaan LKS dalam proses pembelajaran dapat meningkatkan efisiensi, meningkatkan motivasi, memfasilitsi belajar aktif, memfasilitasi belajar eksperimental, konsisten dengan belajar yang berpusat pada siswa dan memandu untuk belajar lebih baik. Kenyataan di kelas 5, nilai pelajaran masih banyak yang mendapat nilai rendah. Ini dlihat dari hasil wawancara dengan ibu Raka, siswa di kelas 5 dalam kemampuan belajar IPA ada yang cukup, dan Berdasarkan hasil angket/kuisioner diperoleh nilai UTS yang masih banyak di bawah rata-rata KKM, hal ini disebabkan karena banyaknya siswa menganggap mata pelajaran IPA yang menakutkan dikalangan siswa kelas 5 SD karena bagi mereka pelajaran IPA sangat sulit dan terkadang tidak mudah dipahami dan membingungkan siswa, Rendahnya hasil pembelajaran siswa disebabkan oleh pembelajaran yang kurang berkualitas.

Sesuai dengan kebutuhan guru dalam mengatasi permasalahan dalam proses pembelajaran pada mata pelajaran IPA, dirasa perlu adanya suatu inovasi baru dalam pengembangan sistem pembelajaran yang lebih menarik, interaktif dan efektif serta efisien dalam pemanfaatannya. Sehubungan dengan hal tersebut, dipandang perlu untuk mengembangkan Media cetak yaitu Lembar Kerja Siswa (LKS) Untuk Meningkatkan Hasil Belajar 
Siswa serta minat belajar pada Mata Pelajaran IPA Kelas V di SD Negeri 1 Banjar Bali, selain dari itu dapat menambah koleksi LKS di sekolah terutama di kelas V.

\section{Metode}

Jenis penelitian ini adalah penelitian pengembangan. Populasi dalam penelitian ini adalah seluruh siswa kelas V SD Negeri 1 Banjar Bali yang berjumlah 30 siswa. Prosedur pengembangan yang digunakan mengacu pada model pengembangan yang dipilih. "Model Pengembangan ADDIE terdiri atas lima langkah, yaitu (1) Analisis (Analysis), (2) perancangan (design), (3) Pengembangan (development), (4) Implementasi (implementation), (5) evaluasi (evaluation)".

Penelitian ini menggunakan dua metode pengumpulan data untuk menjawab permasalahan mengenai rancang bangun pengembangan Lembar Kerja Siswa Bermuatan Karakter. Hasil uji coba Lembar Kerja Siswa Bermuatan Karakter serta efektivitas Lembar Kerja Siswa Bermuatan Karakter yaitu metode kuesioner/angket dan tes. (1) Metode kuesioner/angket merupakan cara memperoleh atau mengumpulkan data dengan mengirimkan suatu daftar pertanyaan/pernyataan-pernyataan kepada responden/subjek penelitian (Agung, 2014:99). (2) Metode tes tertulis merupakan cara mengetahui pengetahuan, keterampilan, intelegensi atau kemampuan yang dimiliki oleh siswa dengan menggunakan serentetan pertanyaan yang berupa tes objektif (Agung, 2014:240). Instrumen yang digunakan untuk mengumpulkan data dalam penelitian pengembangan ini adalah (1) lembar kuesioner (angket) dan (2) soal-soal tes pilihan ganda.

Analisis ini digunakan untuk mengetahui tingkat efektifvitas produk terhadap hasil belajar siswa SD Negeri 1 Banjar Bali kelas V sebelum dan sesudah menggunakan produk pengembangan Lembar Kerja Siswa. Data uji coba kelompok sasaran dikumpulkan dengan menggnakan pre-test dan post-test terhadap materi pokok yang diujicobakan.

Hasil pre-test dan post-test kemudian dianalisis menggunakan uji-t untuk mengetahui perbedaan antara hasil pre-test dan post-test. Pengujian hipotesis digunakan uji-t berkorelasi dengan bantuan microsoft exel dan pemutakhiran hasil dengan perhitungan manual. Sebelum melakukan uji hipotesis (uji-t berkorelasi) dilakukan uji prasyarat (normalitas dan homogenitas).

\section{Hasil dan Pembahasan}

Uji normalitas data dilakukan untuk menyajikan bahwa sampel benar-benar berasal dari populasi yang berdistribusi normal. Distribusi normal artinya data penelitian membentuk kurva norma (lonceng), sehingga perbedaan yang terjadi memang akibat perlakuan bukan perbedaan yang ada pada sampel. Uji normalitas data dilakukan terhadap 30 siswa dari hasil belajar IPA siswa yang diperoleh dari dua tahap yaitu: (1) Pretest (hasil belajar IPA siswa yang mengikuti pembelajaran tanpa menggunakan LKS IPS Bermuatan karakter) dan (2) Posttest (hasil belajar IPA siswa yang mengikuti pembelajaran dengan menggunakan LKS IPA Bermuatan Karakter). Teknik yang digunakan untuk menguji normalitas data adalah uji Liliefors dengan bantuan microsoft excel. Apabila selisih nilai yang terbesar lebih kecil dari kriteria Liliefors nilai, maka dapat disimpulkan bahwa sebaran data berdistribusi normal. Berikut disajikan Tabel 1

Tabel 1. Perbandingan Hasil Uji NormalitasPresent dan Posttest Siswa

\begin{tabular}{lllll}
\hline No & Hasil Belajar & $\mathrm{T}_{0}$ & $\mathrm{~L}_{\mathrm{t}}$ & Keterangan \\
\hline 1 & Pretest & $-0,1170$ & 0,1590 & Normal \\
2 & Posttest & 0,1112 & 0,1590 & Normal \\
\hline
\end{tabular}

Tabel 1 menunjukkan bahwa hasil uji dari uji normalitas tersebut diperoleh $\mathrm{L} 0=-0,1170<\mathrm{Lt}=0,1590$ maka H0 diterima, sehingga dapat disimpulkan bahwa hasil pretes yang berdistribusi normal. Sedangkan hasil uji posttest dari uji normalitas tersebut diperoleh $\mathrm{LO}=0,1112<\mathrm{Lt}=0,1590$ maka $\mathrm{H} 0$ diterima, sehingga dapat disimpulkan bahwa hasil posttest yang berdistribusi normal.

Uji homogenitas mencari kelompok data sampel berasal dari populasi yang memiliki variansi yang sama (Candiasa, 2010:192). Homogenitas data dianalisis dengan uji-F, dengan kriteria data homogen jika $F$ hitung $\leq F$ tabel, dan data tidak homogen jika F hitung $\geq$ F. Uji Homogenitas ini dilakukan untuk mengetahui apakah kedua sampel homogen. Dari perhitungan yang dilakukan diperolah Fhitung hasil belajar IPA siswa adalah 1,22 sedangkan Ftabel dengan dbpembilang $=29$, dbpenyebut $=29$ dan taraf signifikan 5\% adalah 1,86. Hal ini berarti Fhitung lebih kecil dari Ftabel $(1,22<1,86)$ sehingga varians data hasil belajar IPA kedua kelompok adalah homogen. Setelah diperoleh hasil uji prasyarat analisis data, dilanjutkan dengan pengujian hipotesis penelitian. Pengujian hipotesis tersebut dilakukan dengan menggunakan uji-t sampel independent (tidak berkorelasi) dengan rumus polled varians dengan kriteria $\mathrm{H} 0$ tolak jika thitung> ttabel dan $\mathrm{H} 0$ terima jika thitung < ttabel. Hasil analisis uji-t diperoleh $\mathrm{t}$ hitung $=4.077$, sedangkan $\mathrm{t}$-tabel dengan $\mathrm{db}=(\mathrm{n} 1+\mathrm{n} 2)-2=58$ pada taraf signifikansi 
$5 \%=1,67155$. Hasil ini menunjukkan bahwa t-hitung > t- tabel . Oleh karena itu dapat dinyatakan bahwa H0 yang menyatakan bahwa LKS bermuatan karakter efektif diterapkan dalam mata pelajaran IPA siswa kelas V Tahun Pelajaran 2018/2019 di SD Negeri 1 Banjar Bali.

Oleh karena t hitung $>\mathrm{t}$ tabel, maka dapat disimpulkan bahwa nilai posttest lebih baik atau bagus dibandingkan dengan nilai pretest. Sehingga dapat diinterpretasikan bahwa dengan menggunakan Lembar Kerja Siswa IPA Bermuatan Karakter dapat meningkatkan hasil belajar IPA.

Rancang bangun Lembar Kerja Siswa Bermuatan Karakter, Penelitian Pengembangan Lembar Kerja Siswa Bermuatan Karakter pada materi menerapkan konsep perpindahan kalor dalam kehidupan sehari-hari untuk siswa kelas V di SD Negeri 1 Banjar Bali. Langkah-langkah pengembangan Lembar Kerja Siswa seseuai dengan ADDIE. (1) Tahap Analysis (Analisis), (2) Tahap Design (Perancangan), (3) Tahap Depelovment (Pengembangan), (4) Tahap Implementation (Implementasi), dan (5) Tahap Evaluation (Evaluasi). Lembar Kerja Siswa Bermuatan Karakter yang dikembangkan terdiri dari 5 kegiatan belajar yang dikemas menjadi satu Lembar Kerja Siswa, pada setiap kegiatan belajar dikemas dengan mengintegrasikan nilai-nilai pendidikan karakter.

Lembar Kerja Siswa yang dikembangkan memiliki format yang berbeda pada LKS umumnya yaitu: (1) Sebelum mulai materi (judul, prakata, daftar isi, indikator, tujuan pembelajaran, nilai-nilai pendidikan karakter, dan petunjuk Lembar Kerja Siswa), (2) Saat penyampaian materi (kompetensi dasar, materi pokok, uraian materi, dan latihan atau tugas) dan (3) Setelah penyampaian materi (tes mandiri, post test). Pada Lembar kerja Siswa ini terdapat beberapa konten seperti teks dan gambar yang berkaitan dengan pendidikan karakter yang diperuntukkan untuk menunjang isi dari Lembar Kerja Siswa ini agar mudah dipahami oleh siswa dan menarik minat belajar siswa.

LKS ini termasuk dalam kategori media cetak berupa praktikum didalam LKS ini terdapat beberapa kegiatan dimana semua kegiatan tersebut berunsur praktikum/percobaan, di dalam LKS ini tidak ada materi yang begitu membahas tentang setiap kegiatan, LKS bermuatan karakter ini lebih menekankan kepada praktikum dan beberapa pertanyaan setelah melaksanakan praktik, setiap kegiatan di beri kata-kata dan gambar berupa motivasi tentang pendidikan karakter adapun manfaatnya untuk menunjang siswa lebih memahami pendidikan karakter sejak dini.

Pengembangan Lembar Kerja Siswa, terdapat kegiatan-kegiatan yang berupa praktik/percobaan yang akan di praktikkan oleh sekelompok siswa di dalam kelas dan LKS tersebut disesuaikan dengan desain pesan pembelajaran (Sudarma, dkk., 2015) yaitu: (1) Sampul/cover, pada cover ini dikembangkan sesuai dengan kajian analitis desain pesan buku teks diantaranya dalam pemilihan huruf, dipilih huruf yang mudah dibaca sesuai dengan karakter siswa pada permainan edukatif teka-teki silang digunakan font huruf jenis comic san karena merupakan kelompok huruf san serif. (2) Petunjuk penggunaan Lembar Kerja Siswa, disampaikan petunjuk penggunaan yang sistematis dan mudah dipahami oleh siswa. (3) Kompetensi yang akan dicapai, pada bagian ini disampaikan kompetensi inti dan kompetensi dasar. (4) Tujuan pembelajaran yang akan dipelajari, disusun menggunakan formula ABCD (audience, behavior, condition dan degree). (5) Materi, pada bagian ini materi Lembar Kerja Siswa dikembangkan sesuai dengan karakteristik siswa dan konten pada materi Lembar Kerja Siswa menggunakan unsur teks, dan gambar. (6) Tes formatif, sesuai dengan peran Lembar Kerja Siswa sebagai media pembelajaran digunakan kuis berupa essay, untuk mengukur kompetensi siswa sesuai dengan tujuan pembelajaran. (7) Penilaian, pada bagian ini penilaian dilakukan secara manual untuk melatih kemampuan berpikir siswa dalam menjumlahkan nilai yang dihasilkan dari kuis yang mereka dapatkan. Dengan ini, LKS dapat mengoptimalkan peran siswa melalui penilaian yang bersifat terbuka, jadi siswa mengetahui penilaian terhadap hasil yang dikerjakannya.

Validitas Lembar Kerja Siswa Bermuatan Karakter, hasil validitas Lembar Kerja Siswa dari ahli isi mata pelajaran IPA, diketahui bahwa media yang dikembangkan berada pada klarifikasi sangat baik yaitu $100 \%$. Tercapainya kualifikasi sangat baik tersebut dipengaruhi oleh beberapa hal yaitu: (1) dari segi kurikulum sudah sesuai dengan kompetensi dasar, tujuan pembelajaran, dan indikator, (2) dari aspek materi terdapat kemudahan pemahaman mengerjakan praktik/percobaan dalam setiap kegiatan mudah di pahami dan di kerjakan, (3) dari aspek kalimat dan gambar yang disajikan sudah sesuai dengan materi, bahasa yang digunakan dalam penyampaian kegiatan jelas, (4) dari aspek evaluasi sudah sesuai dengan tujuan pembelajaran, dan (5) dari aspek belajar mandiri siswa dapat melakukan percobaan tanpa ada pengajar Jika direview ulang, hasil dari ahli isi mata pelajaran IPA melalui kuesioner skala 5 yang telah dinilai, dari tujuh belas kriteria semua kriteria sudah sesuai dengan isi mata pelajaran dan karakteristik siswa.

Hasil review dari ahli media pembelajaran, diketahui bahwa Lembar Kerja Siswa memperoleh persentase tingkat pencapaian 77,93\% dan berada pada kualifikasi baik. Perolehan kualitas Lembar Kerja Siswa "baik" dikarenakan salah satunya dalam desain pesan teks pada Lembar Kerja Siswa sudah memperhatikan prinsip desain pesan.

Hasil review ahli desain pembelajaran oleh dosen di jurusan Tekonologi Pendidikan, jika direview kembali terdapat sembilan belas kriteria yang tersebar. Kualitas aspek desain pembelajaran terdapat kualifikasi 
sangat baik dengan presentase $92,63 \%$ yang kriteria penilaiannya meliputi: a) kurikulum; b) metode; c) pembelajaran (siswa); dan d) penilaian/evaluasi.

Validasi dalam uji coba perorangan mendapat persentase sebesar 91,20\% dengan kualifikasi sangat baik. Validasi dalam uji coba kelompok kecil memperoleh persentase sebesar 95,11\% dengan kualifikasi sangat baik. Validasi dalam uji coba lapangan memperoleh persentase sebesar 93,76\% dengan kualifikasi sangat baik. Efektivitas Lembar Kerja Siswa Bermuatan Karakter, Efektivitas pengembangan Lembar Kerja Siswa yang dilakukan dengan metode tes pilihan ganda diukur dengan memberikan lembar soal pilihan ganda terhadap 30 orang siswa kelas V di SD Negeri 1 Banjar Bali melalui pretest dan posttest. Data skor pretest dan posttest 30 orang siswa tersebut, maka dilakukan uji-t untuk sampel berkorelasi. Rata-rata skor pretest siswa adalah 13,07 dan rata-rata skor posttest siswa adalah 15,90. Setelah dilakukan penghitungan secara manual diperoleh Hasil analisis uji-t diperoleh $\mathrm{t}$ hitung $=4.077$, sedangkan $\mathrm{t}$-tabel dengan $\mathrm{db}=(\mathrm{n} 1+\mathrm{n} 2)-2=58$ pada taraf signifikansi $5 \%=1,67155$. Hasil ini menunjukkan bahwa t-hitung > t- table. Oleh karena itu dapat dinyatakan bahwa H0 yang menyatakan bahwa LKS bermuatan karakter efektif diterapkan dalam mata pelajaran IPA siswa kelas V Tahun Pelajaran 2018/2019 di SD Negeri 1 Banjar Bali. Dilihat dari konversi hasil belajar di kelas V SD Negeri 1 Banjar Bali, skor rata-rata posttest peserta didik 15,90 berada pada kualifikasi sangat baik.

Menggunakan Lembar Kerja Siswa Bermuatan Karakter dapat memberikan pengalaman baru bagi siswa dalam proses pembelajaran di kelas, serta dengan LKS dapat membantu guru dalam menyampaikan materi dapat lebih maksimal diterima oleh siswa, dan dapat membantu siswa dalam proses belajar yang disampaikan melalui media LKS.

\section{Simpulan}

Kesimpulan dari Penelitian Pengembangan berikut ini :(1) Lembar Kerja Siswa (LKS) Bermuatan Karakter ini berisikan tentang materi panas dan perpindahan yang di kemas dalam bentuk buku cetak dengan konten gambar dan teks agar lebih menarik. Dalam pengembangn media interaktif ini digunakan model pengembangan ADDIE dengan pengembangan produk terdiri dari 5 tahapan, yaitu tahap Analisis (Analysis), Tahap perancangan (Design), Tahap pengembangan (Development), Tahap implementasi (Implementation), Tahap evaluasi (evaluation). (2) Kelayakan Lembar Kerja Siswa (LKS) Berbasis Inkuiri ini berdasarkan uji ahli diperoleh hasil sebagai berikut (1) uji ahli isi mendapakan nilai 100\% dengan kualifikasi sangat baik, (2) ahli media pembelajaran mendapatkan nillai 77,93\% dengan kualifikasi baik, (3) dan uji ahli desain pembelajaran mendapatkan nilai 92,63\% dengan kualifikasi sangat baik). Pada uji coba produk diperoleh hasil sebagai berikut (1) uji peorangan mendapatkan nilai 91,20\% dengan kualifikasi sangat baik, (2) uji kelompok kecil mendapatkan niai 95,11\% dengan kualifikasi sangat baik, (3) dan uji lapangan mendapatkan nilai 93,76\% dengan kualifikasi sangat baik), dengan perolehan nilai dari uji para ahli dan uji coba perorangan, kelompok kecil, dan lapangan, pengembangan LKS secara keseluruhan memperoleh persentase sangat baik dan bisa digunakan lebih lanjut. (3) Hasil analisis uji-t diperoleh $\mathrm{t}$ hitung $=4.077$, sedangkan t-tabel dengan $\mathrm{db}=(\mathrm{n} 1+\mathrm{n} 2)-2=58$ pada taraf signifikansi $5 \%=1,67155$. Hasil ini menunjukkan bahwa t-hitung $>\mathrm{t}$ - tabel .Oleh karena itu dapat dinyatakan bahwa $\mathrm{H} 0$ yang menyatakan bahwa LKS bermuatan karakter efektif diterapkan dalam mata pelajaran IPA siswa kelas V Tahun Pelajaran 2018/2019 di SD Negeri 1 Banjar Bali.

\section{Daftar Pustaka}

Undang-undang No. 20 Tahun 2003 tentang Sistem Pendidikan Nasional. 2003. Departemen Pendidikan Nasional.

Arsyad, A. 2015. Media Pembelajaran. Jakarta: PT. RajaGrafindo Perada.

Asyhar, Rayandra. 2012. Kreatif Mengembangkan Media Pembelajaran. Jakarta: Refrensi Jakarta

Agung, A. A. G. 2014. Buku Metodologi Penelitian Pendidikan. Malang: Aditya Media Publishing

Ernawati, Andi. Misykat, M. Ibrahim,A,A. 2017. Pengembangan Lembar Kerja Siswa Berbasis Multiple Intelligences Pada Pokok Bahasan Substansi Genetika Kelas Xii Ipa Sma Negeri 16 Makassar. Jurnal Biotek Volume 5,No 2, Desember. Terdapat pada http://journal.uin alauddin.ac.id /index. php/biotek/article/download/4276/3999 (Diakses tanggal 27 April 2019).

Fathurrohman, P. H., dkk. 2013. Pengembangan Pendidikan Karakter. Bandung: PT Reflika Aditama.

Febrianti, Erni. Sri,H. Kasmadi,I,S. 2015. Pengembangan Lembar Kerja Siswa (LKS) Materi Larutan Penyangga Model Problem Based Learning Bermuatan Karakter Untuk Siswa SMA. Journal of Innovative Science Education 4 (1). Terdapat pada https:// journal. Unnes .ac.id / sju / index .php/jise/article/view/6890/5841 (Diakses tanggal 27 April 2019).

Sudarma, K. Tegeh, T. \& Prabawa, D. A. P. 2015. Desain Pesan Kajian Analisis Desain Visual Teks dan Image. Yogyakarta: Graha Ilmu

Tegeh, I Made \& Kirna, I Made. 2010. Metode Penelitian Pengembangan Pendidikan. Singaraja: Universitas Pendidikan Ganesha. 
Tegeh, I Made. dkk. 2014. Model Penelitian Pengembangan. Singaraja: Yogyakarta Graha Ilmu.

Zubaedi. 2011. Desain Pendidikan Karakter (Konsepsi dan Aplikasinya dalam Lembaga Pendidikan). Jakarta: Prenada Media Group 